\title{
Khemotaksis Rhizobakteri Osmotoleran pada Rizosfer Tanaman Kacang Hijau (Vigna radiata, L.)
}

\section{Chemotaxis of Osmotolerant Rhizobacteria in Rhizosphere Greenpea Plant (Vigna radiata, L.)}

\section{Yekti Maryani}

Fakultas Pertanian Universitas Sarjanawiyata Tamansiswa

Jl. Kusumanegara 121 Yogyakarta

E-mail:ym-ust@yahoo.com

\begin{abstract}
This research has an objective to study chemotaxis of osmotolerant rhizobacteria strains Al-19 dan M7b in greenpea plant. These isolates were used to inoculate greenpea plant. The study on chemotaxis of osmotolerant rhizobacteria was conducted by CFU method in order to count the number of osmotolerant rhizobacteria AL-19 dan M7b in rhizosphere. Visualization of those isolates on root surface used fluorescence microscope and agglutination reaction with exudates of greenpea root. Result of the study showed that both isolates of osmotolerant rhizobacteria Al19 dan M7b were found in rhizosphere of greenpea with low-density. Simple carbohydrate is substrat that is essential for rhizobacteria to grow thus the chemotaxis of both rhizobacteria is considered as metabolism - dependent. It means that it is not only as digested material but also function as affinity substance. These isolates gathered on the root surface weakly and did not make glutination reaction. This condition indicated that these isolates could not form colony on root surface of greenpea.
\end{abstract}

Key words: Rhizobacteria osmotolerant, chemotaxis, greenpea (Vigna radiata, L.)

\begin{abstract}
Abstrak
Penelitian ini mempelajari khemotaksis rhizobakteri osmotoleran strain Al-19 dan M7b pada tanaman kacang hijau. Isolat ini diinokulasikan pada tanaman kacang hijau. Uji khemotaksis dilakukan dengan metode CFU untuk menghitung jumlah rhizobakteri osmotoleran Al-19 dan M7b di rizosfer. Visualisasi keberadaan isolat tersebut pada permukaan akar menggunakan mikroskop fluorescence dan uji aglutinasi dengan eksudat akar kacang hijau. Hasil penelitian ini menunjukkan kedua isolat rhizobakteri osmotoleran Al-19 dan M7b berada di rizosfer kacang hijau dengan kepadatan rendah. Senyawa karbohidrat sederhana bagi rhizobakteri osmotoleran merupakan substrat tumbuh, sehingga sifat khemotaksis kedua rhizobakteri osmotoleran tersebut dikategorikan dalam metabolism dependent, artinya senyawa yang dapat dicerna yang bersifat sebagai pengikat. Kedua isolat tidak mampu menggumpal dengan uji aglutinasi berarti kedua isolat tersebut menempel lemah pada permukaan akar. Hal itu menunjukkan bahwa isolat tersebut tidak mampu membentuk koloni pada permukaan akar kacang hijau.
\end{abstract}

Kata kunci: Rhizobakteri osmotoleran, khemotaksis, kacang hijau (Vigna radiata, L.)

Diterima: 06 Januari 2010, disetujui: 09 Agustus 2010

\section{Pendahuluan}

Rhizobakteri osmotoleran merupakan salah satu mikroba yang mempunyai sistem adaptasi terhadap tekanan osmotik dengan menganulasi osmolit dalam sitoplasma. Beberapa mikroba dan tanaman dalam kondisi tekanan osmotik akan membentuk senyawa osmolit berupa glisin betain (Munro et al., 1989; Kunin dan Rudy, 1991).

Salmonella typhimurium, Escherichia coli, Klebsiella pneumoniae, Azospirillum amazonense, A. lipoferum, A. brasilense dan A. halopraeferens merupakan bakteri yang telah 
diketahui mampu menghasilkan osmolit bila ditumbuhkan dalam medium dengan tekanan osmotik tinggi (Hartmann et al., 1988). Osmolit sitoplasmik tersebut mampu mereduksi potensial air selular, sehingga lebih rendah daripada potensial air eksternal. Pembentukan derajat potensial air tersebut menyebabkan air mengalir menuju sel, akibatnya turgiditas sel dapat dipertahankan dan pertumbuhan sel dapat berlanjut.

Khemotaksis merupakan mekanisme bakteri dalam menanggapi perubahan komposisi senyawa (chemoeffector) lingkungannya secara cepat dan efisien. Bakteri akan segera mendekati senyawa yang disukainya (chemoattractant), tetapi akan segera menjauhi bila di sekitarnya terdapat senyawa yang membahayakan (chemorepellent) (Bren dan Eisenbach, 2000). Khemotaksis merupakan mekanisme yang diaktivasi karena perubahan $\mathrm{pH}$, suhu, tekanan osmosis, viskositas dan senyawa kimia lainnya misalnya nutrien atau senyawa metabolit sekunder. Respon bakteri terhadap nutrien (asam amino, karbohidrat sederhana dan senyawa organik) merupakan sifat bakteri yang paling mendasar baik secara in situ maupun in vitro dan khemotaksis merupakan langkah awal dalam proses kolonisasi (Bacilio-jimenez et al., 2003). Khemotaksis mendasari fenomena biologi yang terjadi misalnya proses pembentukan biofilm, infeksi pathogen, hubungan asosiatif bakteri diazotrop, pergerakan mikroba dalam air dan tanah serta bioremediasi in situ (Liu dan Papadopoulos, 1996).

Salah satu anggota $\alpha$ Proteobakterium yaitu Azospirillum brasilensis merupakan bakteri diazotrop yang banyak dijumpai pada tanaman sereal dan rumput-rumputan. Bakteri tersebut bersifat mikroaerofilik dan memiliki tipe metabolisme oksidasi yang dapat menggunakan nitrat sebagai akseptor dan sumber energi. Khemotaksis yang terjadi pada Azospillum brasilense bersifat metabolism-dependent artinya hanya senyawa yang dapat dicerna yang bersifat sebagai pengikat. Konsentrasi polihidroksi asam butirat (PHB) dalam sel menentukan tanggapan A. brasilense. Konsentrasi PHB yang tinggi akan mengahalangi tanggapan khemotaksis bakteri. Diketahui bahwa terdapat hubungan langsung antara efisiensi senyawa sebagai growth substrate dan chemoeffector (Alexandre et al.,
2000). Beberapa jenis senyawa aromatik seperti benzoate, cathecol, hydroxybenzoate dan protocatechuate bersifat sebagai pemikat bagi $A$. brasilense pada konsentrasi yang sangat rendah (Lopez-de-Victoria dan Lovell, 1993).

Kolonisasi melibatkan beberapa tahap yaitu khemotaksis rhizobakteri ke permukaan akar, pelekatan rhizobakteri oleh senyawa lectinlike compounds dan perbanyakan diri (Parke, 1991). Kolonisasi merupakan tahap awal yang menentukan dalam interaksi antara rhizobakteri dengan tanaman (Klein et al., 1990). Tahapan lanjut kolonisasi adalah proses pelekatan rhizobakteri pada permukaan akar. Menurut Espinosa-Urgel et al., (2000) protein yang terdapat pada lapisan terluar sangat menentukan kemampuan pelekatannya pada permukaan lingkungan abiotik maupun biotik. Hal ini ditunjukkan adanya mutan Pseudomonas putida, yang tidak memiliki eksolipopolisakarida, ternyata mempunyai kapasitas pelekatan yang rendah terhadap biji dan gagal dalam berkoloni. Permukaan akar tanaman selalu dilindungi oleh selaput tipis lendir yang kaya akan senyawa pektat dan polisakarida. Senyawa yang terkandung dapat menyebabkan reaksi aglutinasi bakteri (Chao et al., 1988). Pelekatan bakteri dapat terjadi karena adanya reaksi aglutinasi antara bakteri dan eksudat akar.

Khemotaksis merupakan tahap awal dalam mempelajari asosiasi antara rhizobakteri dan tanaman kacang hijau. Selain itu khemotaksis menentukan interkasi antara rhizobakteri dan tanaman kacang hijau. Penelitian ini penting sebagai dasar melakukan penelitian lebih lanjut.

Tujuan penelitian ini adalah mengkaji awal mekanisme asosiasi rhizobakteri osmotoleran dengan tanaman kacang hijau guna memperoleh informasi ilmiah tentang mekanisme interaksi awal antara rhizobakteri osmotoleran dan akar tanaman kacang hijau.

\section{Metode Penelitian}

\section{Mikroorganisme}

Dua isolat rhizobakteri osmotoleran yang digunakan yaitu Al-19 dan M7b. E. coli - gfp merupakan bakteri yang berpendar hijau di 
bawah sinar UV. Tanaman kacang hijau yang digunakan adalah varietas bakti.

\section{Isolasi dan Analisis Eksudat Akar}

Eksudat akar untuk analisis biokimia dilakukan dengan modifikasi dari Klein et al., (1988) 200 gram akar tanaman dicuci secara hati-hati menggunakan $400 \mathrm{ml}$ akuades sampai terbebas dari tanah yang melekat. Larutan pencuci tersebut disentrifugasi $800 \mathrm{rpm}$ selama 10 menit untuk memisahkan larutan dengan partikel-partikel tanah yang masih terbawa. Selanjutnya supernatan disaring dengan kertas saring. Supernatan dianalisis kandungan karbohidrat dengan metode HPLC (Settle, 1997).

\section{Transformasi Gen gfp pada Rhizobakteri Osmotoleran}

Bakteri penerima harus memiliki ketahanan terhadap kanamisin dan rifamisin. Bakteri penerima M7b memiliki ketahanan terhadap kanamisin. Untuk ketahanan terhadap antibiotik rifamicin perlu dilakukan pengujian lebih dahulu.

Bakteri M7b atau Al-19 ditumbuhkan dalam LB (Luria Bertani) cair yang mengandung rifamicin $50 \mu \mathrm{g}$ selama satu malam. Bakteri donor $E$. coli pembawa gen pendar hijau (E. coli - $g f p$ ) ditumbuhkan dalam LB cair yang mengandung kanamicin $50 \mu \mathrm{g}$ selama satu malam. Selanjutnya $0,5 \mathrm{ml}$ suspensi $\mathrm{M} 7 \mathrm{~b}$ atau Al-19dan 0,5 ml suspensi (E. coli-gfp) dicampur dalam ependorf, kemudian disentrifugasi dengan kecepatan $13000 \mathrm{rpm}$ selama 5 menit dan diambil peletnya. Setelah itu pelet dicuci dengan $1 \mathrm{ml} 10 \mathrm{mM} \mathrm{MgSO} 4$, selanjutnya disentrifugasi dengan kecepatan 13000 rpm selama 5 menit dan diambil peletnya. Pelet ditambah $10 \mu 10$ $\mathrm{mM}$ MgSO4 divortek dan diteteskan pada medium LB agar, selanjutnya diinkubasikan selama 24 jam. Koloni yang tumbuh diambil dan ditumbuhkan dalam LB cair, digojog semalam. Hasil suspensi ditumbuhkan pada medium agar dalam cawan petri selama 48 jam dan dilihat dengan UV, apabila M7b atau Al-19 memiki pendar hijau, maka transfer gen-gfp berhasil.

\section{Khemotaksis Rhizobakteri Osmotoleran dengan Senyawa Gula}

Uji khemotaksis rhizobakteri osmotoleran terhadap berbagai macam senyawa gula yang dimiliki eksudat akar dilakukan dengan metode Chemical-in-capillary method (Tso dan Alder, 1971). Untuk mendapatkan respon khemotaksis yang baik oleh bakteri maka diperlukan suatu upaya untuk membuat bakteri dalam kondisi kelaparan (starvation). Kondisi ini dapat diperoleh dengan cara menumbuhkan satu ose rhizobakteri osmotoleran dalam $5 \mathrm{ml}$ medium LB semalam. Sebanyak $1 \mathrm{ml}$ suspensi bakteri ditumbuhkan kembali pada $20 \mathrm{ml}$ malate minimum medium selama 2 hari. Komposisi malate minimum medium adalah $10 \mathrm{mM}$ asam malat; $0,6 \mathrm{~g} / \mathrm{l} \mathrm{kH} \mathrm{PO}_{4} ; 0,2 \mathrm{~g} / 1 \mathrm{~K}_{2} \mathrm{HPO}_{4} ; 0,2 \mathrm{~g} / \mathrm{l}$ $\mathrm{MgSO}_{4} ; 0,1 \mathrm{~g} / \mathrm{l} \mathrm{NaCl} ; 0,002 \mathrm{~g} / \mathrm{NaMoO}_{4}, 2 \mathrm{H}_{2} \mathrm{O}$; $0,015 \mathrm{~g} / 1 \mathrm{FeCl}_{3} ; 4,9 \mathrm{~g} / \mathrm{l} \mathrm{KOH} ; 0,025 \mathrm{~g} / \mathrm{l} \mathrm{CaCl}_{2} ; 1$ $\mathrm{g} / \mathrm{l} \mathrm{NH}_{4} \mathrm{Cl}$. Senyawa gula yang digunakan sebagai attractant adalah fruktosa, glukosa dan sukrosa dengan konsentrasi 0,$01 ; 0,1$; dan $1 \mathrm{mM}$.

Untuk menguji respons positif khemotaksis bakteri maka ke dalam kapiler diisi larutan attractant. "Ependorf tip" kuning digunakan sebagai kapiler, caranya dengan mengisi "tip" dengan larutan attractant, kemudian ujung "tip" dibakar dengan menggunakan nyala api. Sebelum digunakan, tip disimpan dengan cara direndam dalam larutan attractant. Selanjutnya kapiler tersebut dimasukkan ke dalam suspensi ('pond') bakteri yang motil. Jumlah sel bakteri yang masuk ke dalam kapiler selanjutnya dihitung dengan metode plating pada medium LB padat. Sebagai kontrol untuk mengetahui tingkat motilitas bakteri, maka kapiler tidak diisi senyawa attractant tetapi diisi dengan akuades steril. Besarnya khemotaksis bakteri dinyatakan dengan jumlah bakteri dalam senyawa attractant yang diukur dengan spektrofotometer $\mathrm{OD}_{600}(\mathrm{Yu}$ dan Roseman, 2001).

\section{Visualisasi Keberadaan Rhizobakteri Osmotoleran pada Akar dengan Mikroskop Flourescence}

Akar tanaman kacang hijau umur 21 hari atau telah mencapai pertumbuhan vegetatif yang diinokulasi dengan isolat Al-19, M7b dan kontrol disterilkan dengan etil alkohol $70 \%$ dan dikocok selama 5 menit dan disterilkan dalam sodium hipoklorit $(6,25 \%)$ selama 10 menit, selanjutnya dibilas dalam air steril 5 kali. Selanjutnya, dilihat dan difoto dengan mikroskop flourecence perbesaran $400 \mathrm{X}$ (Leff dan Leff, 1996). 


\section{Uji Kemampuan Aglutinasi Rhizobakteri dengan Eksudat Kacang Hijau}

Eksudat akar kacang hijau yang digunakan ada 2 macam yaitu eksudat yang diperoleh dari tanaman yang tumbuh dalam kondisi tidak steril (Eks 1) dan eksudat dari tanaman steril (Eks 2). Sebanyak $0,5 \mathrm{x}$ volume suspensi bakteri dalam medium LB cair yang berumur 1 hari ditambah 1x volume $\mathrm{MgCl}_{2} 1 \mathrm{mM}$ dan $3 \mathrm{x}$ volume Eks 1 atau Eks 2. Campuran tersebut diletakkan di atas gelas benda dan dibiarkan selama 10-15 menit. Sebagai kontrol, Eks 1 atau Eks 2 digantikan akuades. Pengamatan aglutinasi dilakukan dengan menggunakan mikroskop fase kontras dengan perbesaran $400 \times$ (Chao et al., 1988).

Pada percobaan ini inokulasi rhizobakteri osmotoleran dilakukan dengan merendam biji kacang hijau dan sisa rendaman disiramkan di rizosfer tanaman kacang hijau. Dari data yang diperoleh menunjukkan bahwa rhizobakteri osmotoleran berada di rizosfer tanaman kacang hijau dengan kepadatan rendah dan mengalami penurunan kepadatan dibanding kepadatan saat pemberian awal $\left(10^{6}\right)$. Rhizobakteri osmotoleran menempel lemah pada permukaan akar tanaman kacang hijau yang terbukti tidak bereaksi aglutinasi terhadap eksudat akar tanaman kacang hijau (Smith, 1987).

\section{Hasil dan Pembahasan}

\section{Isolasi dan Analisis Senyawa Penyusun Eksudat Akar Kacang Hijau}

Eksudat akar berperan penting dalam menentukan jenis bakteri dan proses pelekatan bakteri pada akar. Penyusun eksudat akar disajikan pada Tabel 1. Eksudat akar berperan penting dalam menentukan jenis bakteri yang berinteraksi dengan tanaman. Penyusun eksudat akar dikenali berdasarkan senyawa standar dan komposisi senyawa penyusun eksudat akar disajikan dalam persentase. Eksudat merupakan respons alami tanaman terhadap lingkungan tanaman tempat tumbuh (Hodge et al., 1996).

\section{Transformasi Gen $g f p$ pada Rhizobakteri Osmotoleran}

Transformasi gen $g f p$ ke dalam rhizobakteri osmotoleran telah berhasil dilakukan dan hasilnya disajikan pada Gambar 1 yaitu foto koloni rhizobakteri osmotoleran yang telah mengandung gen $g f p$.

Tabel 1. Komposisi senyawa karbohidrat sederhana penyusun eksudat akar kacang hijau.

\begin{tabular}{cccc}
\hline \hline No. & Senyawa Penyusun & \multicolumn{2}{c}{ Kondisi Pertumbuhan Tanaman } \\
\cline { 3 - 4 } & & Medium tidak Steril (eks. 1) ( \%) & Medium Steril (eks. 2) ( \% ) \\
\hline \hline 1. & Sukrosa & 0,15 & Tidak terdeteksi \\
2. & Glukosa & 2,48 & 0,59 \\
3. & Fruktosa & 0,95 & 0,55 \\
\hline \hline
\end{tabular}

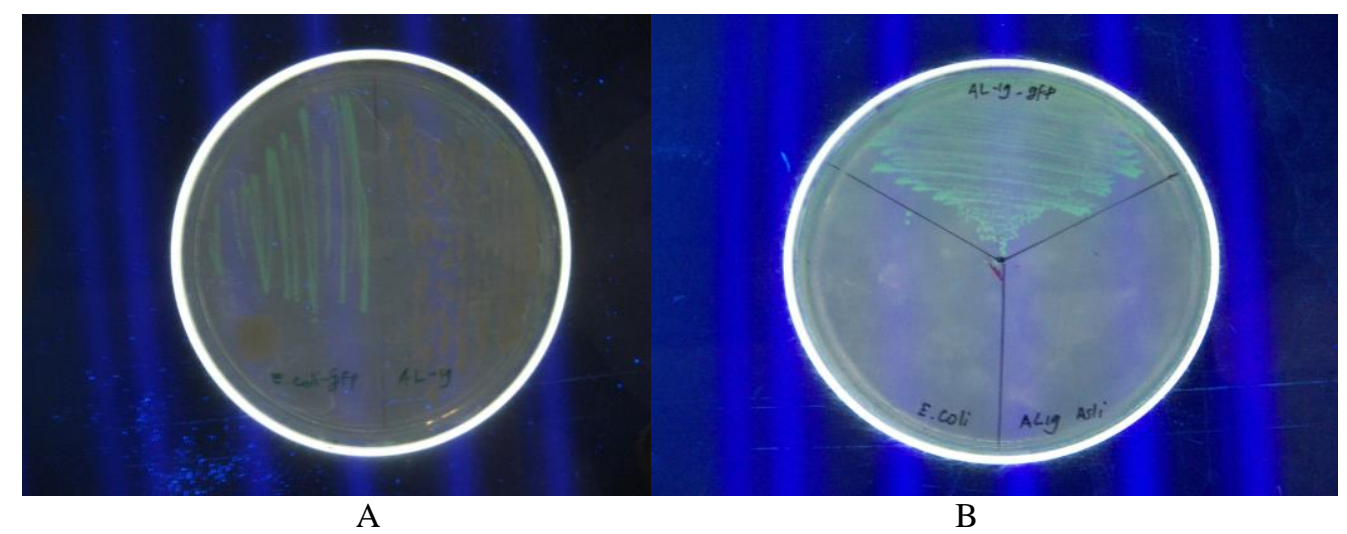

Gambar 1. Koloni rhizobakteri osmotoleran Al-19 diamati dengan sinar UV.

A. Isolat Al-19 asli (tidak berpendar) dan E. coli-gfp (berpendar hijau)

B. Isolat Al-19 - gfp (berpendar hijau), Al-19 asli (tidak tumbuh) dan E. coligfp (tidak tumbuh) 
Penelusuran sifat indofitik rhizobakteri osmotoleran dilakukan dengan menggunakan penanda gen gfp (green fluorescent protein). Dengan menyisipkan gen $g f p$ ke dalam rhizobakteri target akan memudahkan dalam penelusuran kembali rhizobakteri target yang dilepas ke alam. Penyisipan gen $g f p$ secara kromosomal memiliki beberapa keuntungan di antara ketahanannya dalam waktu yang relatif lama(Errampalli et al., 1999; Ramos et al., 2000).

Transformasi gen gfp pada rhizobakteri osmotoleran telah berhasil dengan baik dan penyisipan gen $g f p$ terjadi dalam kromosom rhizobakteri. Errampalli et al., (1999) menyebutkan bahwa transformasi gen $g f p$ banyak ditemukan pada bakteri Gram negatif dan hanya sedikit dijumpai transformasi gen $g f p$ secara kromosomal terjadi pada bakteri Gram positif. Pada penelitian ini $\mathrm{ke}^{-2}$ isolat rhizobakteri osmotoleran merupakan bakteri Gram negatif.

\section{Keberadaan Rhizobakteri di Rizosfer}

Keberadaan rizosfer dapat dilakukan dengan menghitung jumlah rhizobakteri di rizosfer tanaman kacang hijau disajikan pada Tabel 2.

Pada Tabel 2, jumlah bakteri di rizosfer tanaman kacang hijau kepadatannya rendah baik pada Al-19 $\left(3 \times 10^{4}\right)$ dan M7b $\left(2 \times 10^{3}\right)$ dan mengalami penurunuan dibandingkan saat awal isolat diinokulasikan pada tanaman kacang hijau melalui biji dengan kepakadatan $10^{6}$. Hal ini menunjukkan bahwa rizosfer tanaman kacang hijau kurang sesuai untuk rhizobakteri Al-19 dan M7b. Isolat Al-19 dan M7b merupakan rhizobakteri yang diisolasi dari rizosfer alangalang yang hidup pada lahan kritis. Alang-alang merupakan tanaman rumput-rumputan, sedang kacang hijau merupakan tanaman Leguminosae yang di alam bersimbiose dengan rhizobium. Rhizobakteri osmotoleran yang diinokulasi pada tanaman padi gogo ternyata menyebabkan tanaman padi gogo mampu tumbuh pada kondisi sangat kering, dengan kadar lengas 40\% dari kapasitas lapang (Yuwono et al., 1997). Alangalang dan padi merupakan satu kelompok tanaman rumput-rumputan dan rhizobakteri tersebut mampu beradaptasi dengan baik pada tanaman padi.

\section{Khemotaksis Rhizobakteri Osmotoleran Terhadap Eksudat Akar Kacang Hijau}

Simulasi khemotaksis rhizobakteri osmotoleran dilakukan terhadap senyawa karbohidrat sederhana yang terkandung dalam eksudat akar tanaman kacang hijau. Hasil uji khemotaksis rhizobakteri osmotoleran disajikan pada Tabel 3.

Pada Tabel 3 tampak bahwa rhizobakteri osmotoleran memiliki kemampuan khemotaksis terhadap senyawa karbohidrat sederhana yang terkandung dalam eksudat akar tanaman kacang hijau. Tampak bahwa isolat rhizobakteri osmotoleran Al-19 cenderung mempunyai khemotaksis yang relatif lebih tinggi dibanding dengan isolat rhizobakteri osmotoleran M7b.

Senyawa karbohidrat sederhana bagi rhizobakteri osmotoleran merupakan substrat untuk tumbuh sehingga sifat khemotaksis kedua rhizobakteri osmotoleran tersebut dikategorikan dalam metabolism-dependent artinya senyawa yang dapat dicerna dan bersifat sebagai pengikat (Alexandre et al., 2000).

Konsentrasi glukosa dan fruktosa berpengaruh terhadap kemampuan khemotaksis rhizobakteri osmotoleran Al-19 dan M7b. Kemampuan khemotaksis rhizobakteri osmotoleran Al-19 dan M7b semakin menurun dengan menurunnya konsentrasi glukosa, fruktosa dan sukrosa. Konsentrasi sukrosa berpengaruh terhadap kemampuan khemotaksis rhizobakteri osmotoleran M7b. Kemampuan khemotaksis rhizobakteri osmotoleran M7b menurun secara tajam pada konsentrasi sukrosa $0,01 \mathrm{mM}$. Hal ini menunjukkan bahwa terdapat hubungan langsung antara efisiensi senyawa tersebut sebagai growth substrate dan chemoeffector. Semakin efisien senyawa tersebut sebagai growth substrate, semakin kuat pengaruhnya sebagai chemoeffector (Alexandre et al., 2000).

\section{Visualisasi Pelekatan Rhizobakteri Osmotoleran pada Permukaan Akar Kacang Hijau Menggunakan Mikroskop Flouresence}

Pada Gambar 3 tampak bahwa dibandingkan dengan kontrol, kedua isolat rhizobakteri osmotoleran (Al-19 dan M7b) mampu melakukan penempelan pada permukaan akar tanaman kacang hijau.

Pelekatan rhizobakteri pada permukaan akar tanaman kacang hijau secara fisik diamati 
dengan mikroskop fluorescence. Untuk melihat rhizobakteri menempel kuat atau tidak, perlu didukung uji kemampuan aglutinasi. Pada permukaan akar di samping terdapat senyawa yang disukai bakteri, dalam eksudat akar diduga mengandung senyawa lectin-like compound. Senyawa ini yang menyebabkan bakteri mengalami reaksi aglutinasi, sehingga bakteri lebih melekat pada permukaan akar dan tidak mudah tercuci oleh air (Chao et al., 1988).

\section{Uji Kemampuan Aglutinasi Rhizobakteri Osmotoleran dengan Eksudat Akar Kacang Hijau}

Hasil uji kemampuan aglutinasi rhizobakteri osmotoleran dengan eksudat akar kacang hijau, ternyata rhizobakteri osmotoleran isolat $\mathrm{Al}-19$ dan M7b tidak mampu melakukan reaksi aglutinasi dengan eksudat akar tanaman kacang hijau. Reaksi aglutinasi adalah reaksi spesifik yang terjadi antara senyawa glikoprotein yang terdapat pada dinding sel bakteri dengan lectin-like compound yang terdapat pada eksudat akar. Uji aglutinasi pada rhizobakteri ternyata tidak mampu bereaksi aglutinasi. Hal ini menunjukkan bahwa rhizobakteri osmotoleran Al-19 dan M7b tidak mampu melekat kuat pada permukaan akar tanaman kacang hijau, sehingga mudah lepas. Hal ini didukung hasil pemotretan rhizobakteri osmotoleran Al-19 dan M7b yang tampak pada dengan mikroskop flouresense.

Tabel 2. Jumlah rhizobakteri di rizosfer tanaman kacang hijau.

\begin{tabular}{lc}
\hline \hline \multicolumn{1}{c}{ Rhizobakteri Osmotoleran } & Jumlah (CFU/g tanah) \\
\hline \hline Kontrol & 0 \\
Al-19 & $3,0 \times 10^{4}$ \\
M7b & $2,0 \times 10^{3}$ \\
\hline \hline
\end{tabular}

Tabel 3. Uji khemotaksis rhizobakteri osmotoleran terhadap senyawa karbohidrat sederhana penyusun eksudat akar kacang hijau.

\begin{tabular}{|c|c|c|c|}
\hline \multirow{2}{*}{\multicolumn{2}{|c|}{$\begin{array}{c}\text { Senyawa Attractant } \\
(\mathrm{mM})\end{array}$}} & \multicolumn{2}{|c|}{ Jumlah Bakteri (OD $\lambda 600)$} \\
\hline & & Al- 19 & M7b \\
\hline Kontrol & & 0 & $\overline{0,0}$ \\
\hline \multirow{3}{*}{ Sukrosa } & 1 & 0,37 & 0,36 \\
\hline & 0,1 & 0,36 & 0,31 \\
\hline & 0,01 & 0,32 & 0,08 \\
\hline \multirow[t]{3}{*}{ Glukosa } & 1 & 0,39 & 0,35 \\
\hline & 0,1 & 0,37 & 0,29 \\
\hline & 0,01 & 0,34 & 0,09 \\
\hline \multirow[t]{3}{*}{ Fruktosa } & 1 & 0,34 & 0,36 \\
\hline & 0,1 & 0,32 & 0,34 \\
\hline & 0,01 & 0,29 & 0,19 \\
\hline
\end{tabular}

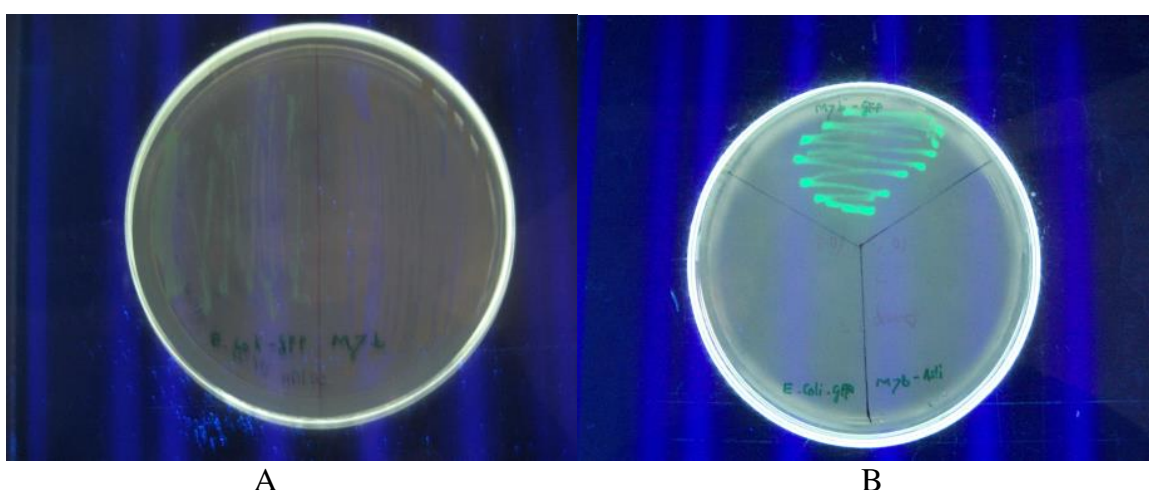

Gambar 2. Koloni rhizobakteri osmotoleran M7b diamati dengan sinar UV.

(A) Isolat M7b asli (tidak berpendar) dan E. coli-gfp (berpendar hijau)

(B) Isolat M7b-gfp (berpendar hijau), Al-19 asli (tidak tumbuh) dan $E$. coli - gfp (tidak tumbuh) 


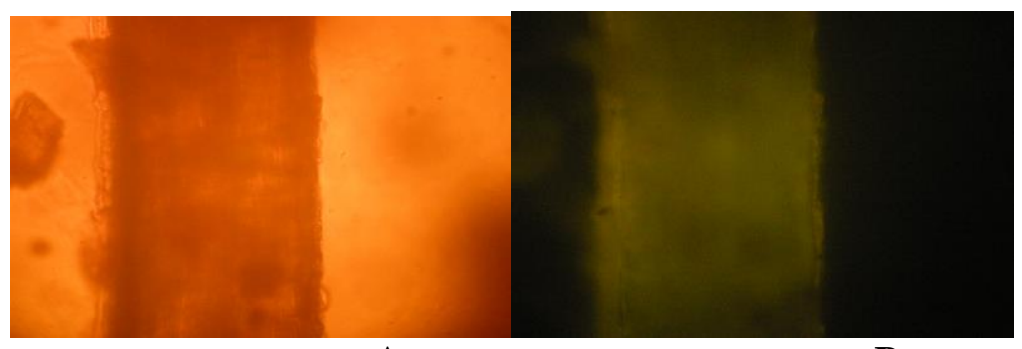

A

B

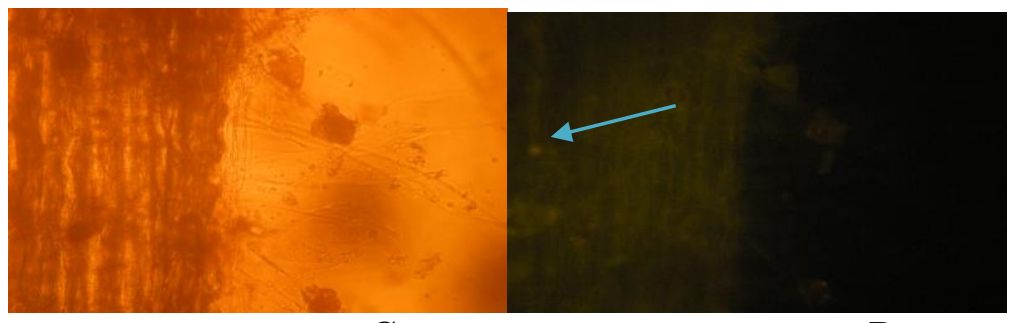

C

D

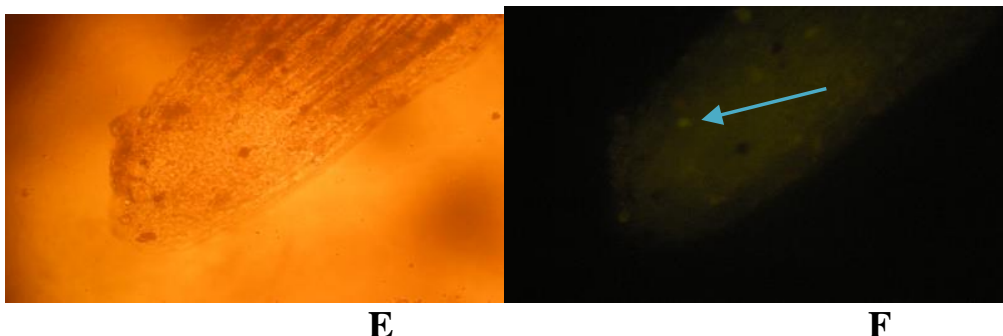

$\mathbf{E}$

$\mathbf{F}$

Gambar 3. Akar kacang hijau yang dinokulasi dengan isolat rhizobakteri osmotoleran dalam medium tanam steril. A dan B Akar tanpa isolat (kontrol); C dan D isolat Al-19; E dan F isolat M7b.

\section{Simpulan dan Saran}

\section{Simpulan}

Rhizobakteri osmotoleran berada di rizosfer tanaman kacang hijau dengan kepadatan rendah yaitu Al-19 sebesar 3,0 x $10^{4} \mathrm{CFU} / \mathrm{g}$ tanah dan M7b sebesar 2,0 x $10^{3} \mathrm{CFU} / \mathrm{g}$ tanah. Senyawa karbohidrat sederhana bagi rhizobakteri osmotoleran merupakan substrat untuk tumbuh. Sifat khemotaksis kedua rhizobakteri osmotoleran tersebut dikategorikan dalam metabolism-dependent atau bersifat sebagai pengikat. Rhizobakteri osmotoleran tidak mampu membentuk koloni pada permukaan akar kacang hijau.

\section{Saran}

Rhizobakteri osmotoleran Al-19 dan M7b memberikan respon khemotaksis positif terhadap karbohidrat sederhana yang terkandung dalam eksudat akar kacang hijau. Penelitian dapat dilanjutkan untuk mempelajari mekanisme asosiasi rhizobakteri Al-19 dan M7b pada tanaman kacang hijau.

\section{Daftar Pustaka}

Alexandre, G., Greer, S.E. dan Zhulin, I.B. 2000. Energy Taxis is The Dominant Behavior in Azospirillum brasilense. J. Bacteriology, 182 (21): 6042-6048.

Bacilio-Jimenez, M., Aguilar-Flores, S., Ventura-Zapata, E., Perez-Campos, E., Bouquelet, S. dan Zenteno, E. 2003. Chemical Characterization of Root Exudates from Rice (Oryza sativa) and Their Effects on The Chemotactic Response of Indophytic Bacteria. Plant and Soil, 249: 271277.

Bren, A. dan Eicenbach, M. 2000. How Signals are Heard during Bacterial Chemotaxis: Protein-protein Interactions in Sensory Signal Propagation. $J$. Bacteriology, 182 (24): 6865-6873.

Chao, Wei-Liang, Ren-Kill dan Weng-Tang Chang. 1988. Effectof Root Agglutinin on Microbial Activities in The Rhizophere. Appl. and Enviro. Microbio., 54: 1838-1841.

Errampalli, D., Leung, K., Cassidy, M.B., Kostrzynska, M., Blears, M., Lee, HH. dan Trevors, J.T. 1999. Application of Green Fluorescent Protein as a Molecular Maker in Environmental Microorganisms. J. Microbiological Methods, 35: 187-199. 
Espinosa-Urgel, M., Salido, A. dan Ramos, J. 2000. Genetic Analysis of Function Involved in Adhesion of Pseudomonas putida to Seeds. J. Bacteriology, 182 (9): 2363-2369.

Harmann A. 1988. Ecophysiological aspects of growth and nitrogen fixation in Azospirillum spp. Plant and Soil $110: 225-238$.

Holge, A., Grayston, S.J. dan Ord, B.G. 1996. A novel method for characterisation and quantification of plant root exsudates. Plant and Soil, 184: 97-104.

Klein, D.A., Salzwedel, J.L. dan Dazzo, F.B. 1990. Microbial colonization of plant roots. In: Nahas, J.P. dan Hagedom, C. (Eds.). Biotechnology of Plant-Microbe Interactions. 189-225. Mc Graw-Hill Inc.

Kunin, C.M. dan Rudy, J. 1991. Effect of $\mathrm{NaCl}$ induced osmotic stress on intracellular concentration of glycine betain and potassium in Escherichia coli, Enterococcus faecalis and Staphylococci. J. Lab. Clin. Med., 188: 217-224.

Leff, L.G. dan Leff, A.A. 1996. Use of green fluorescent protein to monitor survival of genetically engineered bacteria in aquatic environments. Appl. and Enviromental Microbiology, 62: 3486-3488.

Liu, Z. dan Papadopoulos, K.D. 1996. A method for measuring bacterial chemotaxis parameter in microcapillary. Biotechnology and Bioengineering, 51: 120-125.

Lopez-de-Victoria, Geralyne dan Lovell, C.R. 1993 Chemotaxis of Azospirillum sp. to aromatic compounds. Applied and Enviromental Microbiology, 59 (9): 2951-5955.
Munro, P.M., Gauthier, M.J., Breittmayer, V.A. dan Bongiovanni, J. 1989. Influence of osmoregulation processes on starvation survival of Escherichia coli in seawater. Appl. Environ. Microbial, 55: 2017-2024.

Parke, J.L. 1991 Root colonization by Indigenous and Introduced microorganisme. In: Keister, D.C. and Cregan, P.B. (Eds.). The Rhizosphere and Plant Growth. 33-42. Kluwer Acad. Publ. London.

Ramos, C., Molbak, L. dan Molin, S. 2000. Bacterial activity in the rhizosphere analyzed at the single-cel level by monitoring ribosome contents and synthesis rates. Appl. and Enviromental Microbiology, 66 (2): 801-809.

Settle, A. 1997. Handbook of techniques for analysis Chemistry. Academic PRESS. Inc. New York.

Smith, R.S. 1987. Production and quality control of inoculants. In: Elkan, G.H. (Eds.). Symbiotic Nitrogen fixation Technology. 391-412. Marcel Dekker Inc. New York.

Tso, W. dan Adler, J. 1971. Negative Chemotaxis in Escheriachia coli. J. of Bacteriology, 560-576.

Yu, C. dan Roseman, S. 1993. A modified capillary Method for measuring bacterial chemotaxis. In: Gabius, H.J. and Gabius, S. (Eds.). Lectin and glicobiology. 441-444. Springer-Verlag. Berlin. Heidelberg. New York. 